\title{
LEGAL ANALYSIS OF THE USE OF CIRCUMSTANTIAL EVIDENCE THEORY: STUDY OF THE SUPREME COURT DECISION NUMBER 777/Pid.B/2016/ PN JAKARTA PUSAT
}

\author{
Cahya Wulandari \\ Fakultas Hukum, Universitas Negeri Semarang \\ E-mail: cahyawulandari@yahoo.com
}

\begin{abstract}
As the provisions of Article 183 of the Criminal Procedure Code, the system or theory of proof embraced in Indonesia is a negative evidentiary system of law which, in the case of proof, is based on the evidences established in the law which may provide the judge's confidence. Based on the above matter, the existence of Decision Number 777 / Pid.b / 2016 / PN Jakarta Pusat is important to be studied in the judgment. The judge gives the verdict by using circumstantial evidence proof theory. The case was decided entirely using indirect evidence because there was no eye witness or other direct evidence that could prove the indictment. The discussion was conducted using qualitative approach with normative juridical method. Circumstantial evidence is new among practitioners, legal arguments from experts are needed to sharpen the analysis. The juridical review of the use of circumstantial evidence is divided into two categories that are recognized by the KUHAP and which are not recognized. Circumstantial evidence can be a solution for judges in verifying cases that are considered difficult. In a law-based State, the use of circumstantial evidence theory requires the regulation of valid evidence in accordance with the current development of cases.
\end{abstract}

Keywords: Circumstantial evidence, Proof, Decision

\section{A. INTRODUCTION}

The purpose of legal certainty in the implementation of criminal law is very important applied for the realization of justice for both victims and perpetrators. Legal certainty is also an impact of the declaration that Indonesia is a country based on law. So that the legal structure in cracking down and deciding a case should be based on the rule of law that is still valid.

The evidence contained in Article 184 of the Criminal Procedure Code shall be the basis of the parties or judges in the proving of criminal cases. The guilty or innocence of the defendant depends on the evidentiary process presented to the court by both parties. So that the proofing process becomes crucial in determining the fate of the defendant. The judge must carefully consider all the evidence presented to him. Discussing the evidence, the mass media in Indonesia 
had time to present the prosecution of the trial case with suspect Jessica Kumala Wongso. The case of alleged premeditated murder committed by the perpetrator by piercing cyanide poison in a cup of coffee then drunk by victim I Wayan Mirna Salihin. After a series of unfinished hearings, on October 27, 2016 the verdict was handed down by sentencing the defendant 20 years in prison. In addition to the many court proceedings that attracted the masses, few paid more attention to the principal considerations of judges in the ruling. The judge uses a new term in the science and practice of criminal procedural law in Indonesia. In the verification process at the hearing, the judge could not find any direct evidence that the perpetrator applied cyanide to the victim's coffee.

Therefore the judge used the theory of circumstantial evidence in the proof to impose a guilty verdict against the perpetrator. Circumstantial evidence is a theory of evidence that indirectly indicates that the defendant was the perpetrator. This theory of evidence that the judge uses as a basis for judgment. Whereas the judge should be limitatively assuming that the valid evidence is contained in Article 184 of the Criminal Procedure Code.

New findings emerging from the legal practitioners, in this case the judge, in deciding a case of course requires more in-depth study. What are the things behind the use of circumstantial evidence as evidence in the decision. The judge's conviction and two evidences are sufficient according to the Criminal Procedure Code to ensnare the defendant with a guilty verdict. The two instruments are interrelated because the emergence of beliefs must be based on sufficient evidence presented in the hearing as provided for in Article 183 of the Criminal Procedure Code.

Circumstantial evidence as evidence presented in court does not originate directly from eyewitnesses or participants of the crime. It can be physical evidence or circumstances in which a plausible explanation may prove that the indirect evidence is a contributing factor as well as explanation of the crime. The use of circumstantial evidence in this new criminal case is used in the case of premeditated murder with the accused Jessica Kumala Wongso Decision Number 777 / Pid.B / 2016 / PN Jakarta Pusat This should be further analyzed on the evidence this is academically to ensure justice for all parties.

\section{B. PROBLEM STATEMENT}

Based on the introduction, this article analysis how the legal analysis of the use of circumstantial evidence theory: study of the supreme court Decision Number 777/pid.b/2016/ PN/ Jakarta Pusat? 


\section{RESEARCH METHODS}

This study analyses the Decision Number 777 / Pid.B / 2016 / PN Jakarta Pusat which was published on October 27, 2016. In the verdict there are new findings conducted by legal practitioners, in this case the judge, deciding the organized murder case that need to be described objectively about the validity of the scientific aspect as well as the law aspect. In accordance with the qualitative research approach, this study aims to gain an understanding of the use of circumstidential evidence theory in proving criminal cases in Indonesia. The main data are secondary data obtained from library research. This research requires primary data source as strengthening of library research result. This is because circumstancial evidence is new among law practitioners so that legal arguments from experts are needed to sharpen the results of research.

\section{DISCUSSION AND RESEARCH RESULT}

\section{D.1. Juridical Review On The Use Of Circumstantial Evidence Theory in Criminal Case Number 777 / Pid.B / 2016 / Pn Jkt Pst The Use of Circumstantial Evidence}

Colin Colin Evans shares evidence in two categories, direct evidence and circumstantial evidence (Colin Evans, 2010: 7). Based on the results of interviews with Eddy OS Hiarej, the two evidences can be presented in the trial and each can stand alone. But according Colins Colin Evans both have a significant difference of proof power (Colin Evans, 2010: 7). To distinguish easily, as the description of the article "Direct and Circumstantial Evidence" (www.mass.gov, 2009) the following example can distinguish direct evidence and circumstantial evidence:

"Your daughter might tell you one morning that she sees the mailman at your mailbox. That is direct evidence that the mailman has been to your house. On the other hand, she might tell you only that she sees mail in the mailbox. That is circumstantial evidence that the mailman has been there; no one has seen him, but you can reasonably infer that he has been there since there is mail in the box."

The above example can be concluded that the difference between the two lies in what the witness saw himself. Direct evidence is a tool of evidence that can point directly that the defendant who committed a criminal offense while circumstantial evidence can not prove so. The use of indirect evidence in Indonesia is still minimal because of the need to be careful in deciding cases. Judge as a law enforcement spear in dropping the verdict, certainly has a heavy burden in applying evidence circumstantial evidence. 
The use of indirect evidence has been used in legal proceedings in the Semarang District Court. The case is the alleged murder of Suyati's grandmother (59) who originated the theft. The perpetrators were a group of 4 defendants, one of whom was shot dead during the arrest. The case begins when Grandma Suyati's house smoke out so that neighbors around her house see and find Grandma Suyati killed in her room. This creates irregularities among the neighbors because there is a gas cylinder that is missing and lying in the room. Grandma Suyati also used to scream for help if need help, but that night did not happen that way. The defendants were charged with the Cumulative Indictment Article 339 of the Criminal Code concerning Murder jo Article 55 Paragraph (1) of the Criminal Code and Article 365 of the Criminal Code (2) on Theft with Violence. However, in its verdict, the judge sentenced all three defendants to the entire charge of the Public Prosecutor. The judge argued that during the trial there was not enough evidence that all three had taken the lives of others. Related to the second indictment, there were no witnesses who knew the victim's belongings were missing. Therefore, against this second indictment also the Panel of Judges frees the defendants. Because the incident was not a single eyewitness so that proof is difficult. Regarding the investigation of missing items also has difficulties because the victim's home is burned so that the proof of theft theft is hard to prove by the judge. Although in the investigation process the three defendants admitted their actions to the reconstruction of the incident of the suspects to explain in detail the crime committed. However, in the trial process, all three of them declare to revoke the investigation report that the information is taken under the pressure of the investigator accompanied by torture and without legal counsel.

One example of the use of circumstantial evidence in the United States is the case of Scott Lee Peterson who is accused of killing his pregnant wife. He was sentenced to death with evidence that is entirely a circumstantial evidence. The body of Scott Lee Peterson's wife was found on the San Francisco coastline. The proofs are two hand-made anchors found by Peterson and a haircut found on his ship, consistent with Peterson's wife's DNA. The proof is not direct evidence, as no witnesses witnessed it.

Assessing the judge's ruling is a necessary thing, especially the legal process is the determination of the life of a defendant or more. The impact of the verdict not only strikes the defendant but will penetrate a very broad target, whose understanding can not be understood in a linear way because the judicative product is an output of a fairly complex social process (Muladi and Barda Nawawi Arief 1995: 105). This means that the background of a defendant commits a crime, the way the accused does so, based on a social development that exists within society. So the impact of a decision not only affects the law itself but all forms of 
science involved in the legal process can also be affected.

At the time of the judgment of the verdict, much to the attention of academics on the theory of circumstantial evidence evidence used by judges. In fact, the Public Prosecutor did not find any direct evidence suggesting that the defendant had incorporated cyanide poison into the victim's VIC. In the verdict, the Panel of Judges can not clearly describe when Jessica put Cyanide poison into the VIC. In its judgment, the Panel of Judges stated that the premeditated murder is very difficult to prove because it has been planned in such a way that there is no direct evidence that could indicate that the perpetrator has committed the offense. Based on the decision, the Panel of Judges stated that there are 3 (three) ways that can be done as a way out in such conditions, namely:

1) The judge is free to choose what evidence to use in deciding the case in accordance with the free beuis theory or free evidence. This means that judges are not bound by certain evidence.

2) The use of circumstantial evidence or indirect evidence

3) The use of objective theories are objectified

These three things will be used by the Panel of Judges in deciding this case. The above consideration states that the judge uses vrijs bewijstheory. In the literature, the theory is equated with conviction raissonee or theory of evidence based on judge's conviction for logical reasons. However, in the verdict, the Panel of Judges stated that:

First, formally, the criminal law of proof in principle has the same and equal verification value except that the defendant's evidence is lower than other evidence. Because according to Article 189 paragraph (3) of the Criminal Procedure Code stated that the defendant's statement is only valid and used on his own that according to the defendant's statute lawyer presented in the court can only benefit himself. If he tells the truth and if he lies it will be the things that lighten and incriminate the punishment by the judge, therefore in the context of criminal proof law is known as vrijs bewijstheory or free evidence. This means that the judge is not absolutely bound to any particular evidence. However, depending on which evidence is believed to be mutually compatible with each other as contained in Article 184 of the construction explanation Article 184 of the Criminal Procedure Code (KUHAP) stipulates legal evidence to refer to valid evidence in the order of: (a) the statements of witnesses; (b) Expert description; (c) Letter; (d) Guidance, and (e) Description of the defendant. That is why the judge will ultimately choose a minimum of two valid evidences and the judge believes that the defendant committed the crime or not. Then the judge will be able to impose a criminal or acquit the defendant. 
Although the judge declared that he was using vrijs bewijstheory, the judge continued to limit his reasons to the valid evidence so that it could be concluded that the Panel of Judges was still obedient to Article 183 of the Criminal Procedure Code with the theory of evidence based on the law negatively. Because judges continue to limit their belief in legal evidence by law.

This is in accordance with the existing Indonesian Criminal Procedure Code (KUHAP) which applies law system negatively. The actualization of the system is contained in Article 183 of the Criminal Procedure Code. Thus, in deciding the case the judge must be convinced that it is based on at least two evidences that have been faced in the hearing. The difference with the conviction system of raissonee is negatief wittelijk must be based on the evidence already prescribed by law but the conviction raissonee judge has the freedom in determining the underlying reason for his belief. The following is the provision of the evidentiary system contained in the Criminal Procedure Code along with the restriction of evidence that is legally recognized by law.

Particularly in this discussion, the author will describe the use of circumstantial evidence in this decision. More details, passage of decision on second point above is:

"Formally to prove a crime does not have to be an eyewitness who saw the act. That is, if a murderer uses poison as a delicti instrument or goods used to commit a crime then the poison is put into the drink then there should be no eyewitness who saw the poison is put into the drink. To prove that the Prosecutor or Judge can use the circumstantial evidence or indirect evidence."

Circumstantial evidence can also be called indirect evidence. Both words are equally meaningful indirect evidence. To prove a crime, Indonesia recognizes the theory of evidence by law in a negative way. It is this theory that underlies the decision of judges in Indonesia in deciding cases. Furthermore, the Criminal Procedure Code does not specify the two evidences to which should be so that the words of a judge stating that in proving a criminal offense there should be no eyewitness or eye wittnes is true.

This is a legal argument underlying the use of circumstantial evidence in Decision Case No 777 / Pid.B / 2016 / PN Jakarta Pusat. Legal argument or legal reasoning in terms of language, the term 'argument' is defined as trying to entrust others by asking the reasons (Ranuhandoko, 1996: 67). In the Dictionary of Philosophy, the 'argument' or 'arguere' which means explaining (Jalaluddin Rakhmad, 1995: 22). Reasons (evidence) are offered to support or deny something. Although at first many agreed that legal reasoning was only motivated by the purely political interests described in Brett G. Scharffs article: (Scharffs: 2004: 733). 
"Some have argued that legal reasoning is essentially political, and that judges do, or should, decide cases based on their vision of what is politically correct. Such a judge may serve the master of her own ideas of what is good or right, or may serve political masters and their view of what is good and right. Others maintain that legal reasoning is essentially moral."

The above article, mentioned not only the political reasons behind the use of legal reasoning but also moral reasons. As written by Kusnu Goesniadhie (http://www.pa-kandangan.go.id/index.php), the legal argument is the explanation of a clearly described description, a series of statements logically, to reinforce or reject an opinion, establishment or idea, in relation to legal principles, legal norms and regulations of concrete law, as well as legal system and legal discovery. The notion of legal reasoning is used in two meanings, namely in a broad and narrow sense. In a broad sense, legal reasoning is related to the psychological process the Judge conducts, to arrive at a decision on the case he faces. Legal reasoning studies in a broad sense involve aspects of psychology and biographical aspects.

Legal reasoning in a narrow sense relates to the argumentation underlying a decision. This study involves studying the logic of a decision. In relation to the types of argumentation, the relationship between reason and decision, and the accuracy of the reasons or considerations that support the decision.

William R Bell was quoted by Eddy O.S. Hiarej (2012: 54) states that the circumstantial evidence (evidence indirectly) means evidence that indirectly points to a fact, but the evidence can refer to the actual event. Illustration of the chart below will facilitate an understanding of the meaning of circumstantial evidence.

The evidence can be obtained from letters, witness statements, expert statements, or defendant's statements. Eddy OS Hiarej when asked about the possibility of convicted defendant Jessica Kumala Wongso without using circumstantial evidence referring to the theory of evidence embraced by KUHAP in Article 183 states that the case without any circumstantial evidence the defendant can not be found guilty of committing murder because there must be two evidence. In obtaining evidence and related isntruments are also quite difficult, but to bring a case to court then at least met the minimum standard of evidence embraced in the system of evidence according to KUHAP, namely 2 evidences in accordance with Article 183 KUHAP. From the answer the author can conclude that the circumstantial evidence is any evidence that can not directly show that the defendant is guilty of committing a crime.

Circumstantial evidence does have its own flaws and advantages when applied, especially in Indonesia. Not all judges have the instinct of being a good 
law enforcer. So the use of circumstantial evidence should be applied carefully. Regarding the application of circumstantial evidence there is no clear parameter so that the abuse of judges in using circumstantial evidence is more likely to be high. In addition, a judge who still has a positivistic-legalistic view assumes the circumstantial evidence out of the evidentiary system it embraces.

Apart from that weakness, actual circumstantial evidence can be an alternative way for judges to prove material truth. Circumstantial evidence can compensate for the development of criminals in carrying out their actions. Technological advancement and the development of human thought are experiencing significant progress thus affecting the way the perpetrator in committing a criminal act. This will undoubtedly complicate the proofing process because of the lack of eyewitnesses so that circumstantial evidence can be a solution in the proving of a criminal case.

Before explaining the juridical review of the use of circumstantial evidence, it is necessary to know in advance what is included in the circumstantial evidence of Decision Case No 777 / Pid.B / 2016 / PN Jakarta Pusat in sequence. The verdict in this case is entirely a circumstantial evidence because there is no eye wittnes or eyewitnesses or other direct evidence that can prove that the defendant killed Mirna. It should be noted, however, that the Criminal Procedure Code has regulated the legal types of evidence in Article 184. Thus, the use of circumstantial evidence can not all be used.

Judge in Decision Number 777 / Pid.B / 2016 / PN Jakarta Pusat acknowledges 78 facts proven to be obtained from witness statements, expert statements, letters, instructions and explanations of the defendant. All these facts come from circumstantial evidence. The following summary is presented under Decision No 777 / Pid.B / 2016 / PN Jakarta Pusat pages. 316-331.

\section{Witness Statement}

a. Witness Marlon as a server stating that the VIC straw served has been in the glass, whereas previously presented by Agus Triono in a state still wrapped.

b. Description of Witness Hanny, Devi Crisnawati, Marwan Amir, and Agus Triono stating that the VIC ordered by the defendant is yellowish in color like turmeric and tastes bitter and hot on the tongue. The scent of VIC is also considered unnatural by witnesses.

c. Hanny's description stated that the victim felt hot to his tongue shortly after drinking the VIC.

\section{Expert Description}

Expert description stating that the victim collapsed due to a combination of toxic 
effects and corrosive effects contained in Sodium Cyanide. The corrosive effect is the heat and finally the seizure, the breath puffing up against the sova indicates that the defendant ran out of oxygen and collapsed.

\section{Letter}

a. The minutes of the witness examination of Cristy who was unable to attend the trial stated that the defendant had various problems including attempted suicide.

b. Visum et Repertum stating that the lips in Mirna's victim are bluish in color due to corrosive material according to the expert's statement that Sodium Cyanide is corrosive.

c. Visum et Repertum Psychiatrum Number: TU.02.02 / IX.15.10 / 0330/2016 dated March 15, 2016 states that the defendant has the risk of repeated acts of violence against himself or others when he is in a pressure situation and does not receive social support. adequat.

\section{Instructions}

a. CCTV and testimony proving that the defendant purchased 3 soaps, each wrapped in a pappper bag before sitting in Cafe Olivier and it was believed that the paperback was deliberately purchased and placed in the center of the table to cover its activities against the victim's coffee cups from CCTV or from other visitors.

b. CCTV which proves that the defendant came almost two hours earlier than the agreement with his friends through WhatssApp is believed to be the judge as the time to plot the murder.

c. CCTV that shows the trdakwa brjalan mnuju c cashier to pay bill Bill closing while taking a look and the situation and kdaan in Cafe Olivier

d. CCTV which showed the defendant scratching his right hand and thigh shortly after the victim Mirna Kolaps and the defendant stood up from the chair on the orders of Witness Devi Crisnawati. In accordance with the expert's statement stating that the effects of Sodium Cyanide if exposed to the skin will be itchy. It is believed the judge as an indication that the defendant has held Sodium Cyanide.

5. Defendant's Statement: in this case the defendant did not acknowledge his actions

In Decision Number 777 / Pid.B / 2016 / PN Jakarta Pusat, The Panel of Judges first, consider the "deliberate" element before the judge proves the motive of the alleged act to the defendant. According to the Panel of Judges, the motive of the accused committed a crime of premeditated murder was due to hurt and 
resentment. In this case it is clear that the judge uses indirect evidence because the inner attitude is abstract and the defendant does not acknowledge his actions. External circumstances that appear to be concluded by the Panel of Judges to cause the motive is the meeting of defendants, victims, and husband of victim Arif. So cause envy to see a happy partner but on the other hand the victim had suggested to the defendant to decide his girlfriend.

Here the judge's judgment in proving the intent of the defendant committed a crime of premeditated murder to the victim I Wayan Mirna Salihin.

"Considering that to know the existence of deliberate elements can be found 3 days after the victim Mirna died seen SMS conversations between Jessica with Sandy Twin Mirna. On January 7, 2016 witness Sandy received an SMS from the Defendant continually asking what the forensic laboratory results for Mirna's victims. Because Sandy Witness did not yet know the result did not answer the question of the Defendant. This indicates that the defendant Jessica has been proven to plot the murder so as to make herself very anxious to know the cause of Mirna's death due to cyanide. If it is known that the cause of death from cyanide toxicity would be a big problem to Jessica but if it proved not for cyanide then the better chance for him by the Defendant has successfully fooled the community that the cause of death was not due to cyanide and a link to Sandy witness about coffee a potentially toxic fake that was sold in Vietnam before Mirna died. From this evidence even witness Sandy did not think that the victim Mirna died because of poison. This guidance, according to the Panel of Judges, has proven that there is an intention to kill Mirna's victims."

The incident claimed that the defendant questioned the forensic results of the forensic laboratories to Sandy's witnesses continuously and the link sent by the Defendant Jessica was evidence of circumstantial evidence convincing the Panel of Judges that it refers to the fact that the defendant is in anxious state if his act of killing Mirna using Sodium Cyanide is known in victim examination. Based on the facts obtained from the testimony of the witness Salihin Sandi can be drawn the conclusion refers to the fact prosecuted by the Public Prosecutor that the defendant who killed the victim Mirna. The facts of the defendant's question Jessica and the link address sent by the defendant to Sandy Salihin are collaborating evidence which is evidence of mutual support. The reason there are two fact clauses or more because the circumstantial evidence is not based on observation or knowledge, but based on a conclusion of the facts (Max M Houck, 2009: 2). This indirect proof becomes the basis for the fulfillment of the "intentional" element in Article 340 of the Criminal Code in accordance with the indictment of the Public Prosecutor: 
"Considering that in relation to the personality of the Defendant who remained unremarkable, calm when the victim Mirna suffered a disaster, was just silent so that Devi's witness was forced to ask the Defendant not to stay silent and help his ailing friend. So just moved to the victim and took the victim to the chair and while the defendant scratched his hands and thighs through CCTV proved that the defendant's behavior was an indication that the defendant was confused and suspected of the scratching of his hands because of the cyanide poison that was exposed to the hands of the Accused because of his actions it does not expect to be that way. That is why the defendant quickly deleted the data and left the group whereas previously it was terdawa who had initiative to open chat application among his friends like Hanny, Mirna, and Vera."

Initially the Panel of Judges admitted the fact that Jessica was calm when Mirna's victims collapsed. But then after the defendant stood up, and was seen scratching, the Panel of Judges had two interpretations that were still alleged. Should, in the judgment of all considerations be based on the fact that the judge believes the truth. The scratching activity of the hands by the Assembly is considered to be confused as well as allegedly itchy because of the cyanide poison that is affecting his hands. It can be classified as indirect evidence. The allegations do not have sufficient grounding because cyanide ownership of Jessica can not be proven by the Panel of Judges in the decision. According to Jan Remmelink, professor and former Dutch Attorney General, there are three important matters in the premeditated murder as provided for in Article 340 of the Criminal Code. First, the offender when deciding the will to do in a state of calm. Secondly, there is a considerable grace period between deciding the will and performing the deed. Third, the implementation of the deed is done in a state of calm.

The Panel of Judges' interpretations of anxious and confused defendants are certainly not included in the terms filed by Jan Remmelink because the defendant was in an uneasy state and in the possession of two cocktails of high alcoholic dosage previously proved by the Panel of Judges himself. But the Panel of Judges did not consider it.

Improper relationship between Defendant Jessica and Victim Mirna was obtained from the instructions through the suitability of expert information and CCTV. This evidence is not included in the guidance evidence as evidence of clues can only be obtained from witness statements, defendant's statements, and letters. While the expert information can not be used as a guide. The use of this expert testimony should be reviewed in more detail in its Decision Number $777 /$ Pid.B / 2016 / PN Jakarta Pusat.

The information of an expert acknowledged in Indonesia under the General Provisions of the Criminal Procedure Code is the information provided by a 
person who has specific expertise on what is necessary to make the light of a criminal matter in the interest of examination and in Article 188 of the Criminal Procedure Code that the expert's statement is what an expert in the court to make light of a criminal case. However, regarding the type either in the Criminal Procedure Code or the explanation of Article 188 of the Criminal Procedure Code, there is no further understanding of what conditions must be fulfilled in giving testimony in the hearing.

\section{D.2 Juridical Review Use of Circumstantial Evidence in Decision of Case Number 777 / Pid.B / 2016 / PN Jakarta Pusat.}

The limitation of the authority of law enforcers into benchmarks is their obedience to the burden of proof that is applied objectively, structurally, and rationally, and humanely (Syaiful Bakhri, 2015: 44). Proof is a central point in the process of achieving justice in the midst of society. The law of proof, in litigation, is a very complex part of the legal process. The complexity of the situation is more complicated, because the proof is related to the ability to reconstruct events or past events as a truth. The criminal judge in conducting the proof assumes a completely free role. Unlike civil judges whose duties are limited by binding and coercive evidence. The real problem of proof lies in the burden of proof that must be fair and is a juridical issue that can be pursued through the existing legal channels. Examination of court decisions, whether it be first level, appeal, cassation, or review becomes an academic activity that practitioners, academics, or the public can perform in guarding the law enforcement process in Indonesia. Cases with Decision Number 777 / Pid.B / 2016 / PN Jakarta Pusat are also interesting in exploring the sciences used in law enforcement practices in the decision.

The use of the theory of expert opinion is certainly ratified in the imposition of a criminal to the Defendant by the Panel of Judges. Expert opinion or doctrine is recognized as a source of law in Indonesia. Criminal law recognizes written law as the main source of law (Barda Nawawi Arief, 2009: 23). Therefore, the use of theory must be appropriate in providing expert opinion in imposing criminal verdict. Therefore, the use of circumstantial evidence needs to be limited in such a way in its use because not all circumstantial evidence is valid and applicable under the Criminal Procedure Code.

According to Eddy O.S. Hiarej, the use of circumstantial evidence is not explicitly stated in the law. Yet the use of theory or doctrine is recognized as one of the five existing sources of law. So as long as the use of such theory can 
underlie the judge's conviction, then the judge may use it. Based on the results of interview with Eddy OS Hiarej in April 2017 stated that

Circumstantial evidence is indirect evidence and then based on existing facts can be proven whether it is from the letter, from the testimony of witnesses, expert information, or the statement of the defendant then obtained the conclusion, the judge may decide in the absence of direct evidence.

\subsubsection{Circumstantial evidence recognized by the KUHAP}

a. Circumstantial evidence in witness testimony

An example given by Eddy OS Hiarej (2012: 53) in distinguishing direct and indirect evidence in his book through the parable of someone who was shopping at a supermarket saw with their own eyes the robber fired at the cashier until the cashier was killed. The testimony of the person is direct evidence. Compare if someone who hears a gunshot then runs toward the sound and arrives just to find the body lying and someone holding the gun. The second person's description of the gunshot is a circumstantial evidence because it requires further proof to ensure that the person holding the gun is the one who killed the dead cashier. Examples of such testimony are legitimately used in the proving of criminal cases in Indonesia because the indirect evidence is obtained from the testimony of the witness. Provided that the witness only explains the items he or she has heard, seen and experienced without any opinion.

A note to remember is that circumstantial evidence requires other means of evidence to corroborate such indirect evidence. This is in line with Article 185 paragraph (2) of the Criminal Procedure Code which states that the testimony of a witness alone is not sufficient to prove that the defendant is guilty of the act that is accused of him. The testimony of the witnesses, whether direct evidence or circumstantial evidence, must be corroborated by other evidence, whether in the form of testimony of another witness, expert statement, statement of defendant, or documentary evidence in accordance with Article 185 paragraph (2) of the Criminal Procedure Code. There are 2 (two) conditions concerning witness testimony that can not be separated so that the witness's statements are valuable and worthy of proof, are: (1) regarding the source of witness knowledge; (2) regarding the substance of the testimony of witnesses (Adami Chazawi, 2008: 44).

Article 1 point 27 states that the testimony of a witness is a 
description of a criminal incident. The term criminal event should not be defined as a criminal act in the strict sense or only a crime containing its elements as defined in the law only, but is an event that has arisen in a clear manner in which there is a certain offense. The witness's statements come from his own eyesight, his own hearing, and the events he experienced himself. The source of the information can not be obtained from others, notices or stories of others, or in the doctrine referred to as testimonium de auditu or hearsay evidence.

The substance of the testimony of the witness must be facts. Regarding the contents of witness statements are not regulated in law. In essence, the contents of witness statements are relevant / related to the proof of the accused crime, the defendant doing so, and the defendant's wrongdoing (Adami Chazawi, 2008: 46).

\section{b. Circumstantial evidence in the expert's statement}

The expert's true information is an indirect evidence because in his statement, the expert does not discuss the subject matter or does not see or know the crime committed by the defendant. The expert testimony may state the opinions and conclusions of the topics described by the limitations to express explicitly. Usually the witness only answers questions in the form of hypotheses. Based on this pattern, the expert should not provide an assessment of the case being heard. Expert information in the form of opinion is general on the basis of knowledge and experience so neutral and impartial (Eddy O.S. Hiarej, 2012: 67). Assessment of expert information is left entirely to judges who consider it wisely and wisely.

The role of expert evidence in Case Number 777 / Pid.B / 2016 / PN Jakarta Pusat is significant. In the trial, the Public Prosecutor presented 11 experts to give testimony before the trial. While based on Decision Number 777 / Pid.B / 2016 / PN Jakarta Pusat, the Legal Counsel presents 13 experts in this case. Broadly speaking, expert information can be divided into two, namely: (a) the expert's opinion on a matter which is the subject of a case in the court on the basis of a knowledge or expert experience expressed in the hearing without requiring an earlier action; (b) expert opinion on the basis of an action to be performed before a trial such as examination, research, or observation. 
Both types of expert information are contained in this case. Such inordinate expertise, in judgment, the judge shall judge the expert information from which the Panel of Judges may gain confidence.

\section{c. Circumstantial evidence in letter proof}

In fact, the evidence of a letter can not directly show the offender charged to the defendant. The existence of a minimum of verification in terms of formal evidence of a letter is a valid evidence and can stand on its own. However, for perfect value, letter proof must be subject to the theory of evidence contained in Article 183 Criminal Procedure Code which underlies a minimum of 2 evidences to obtain the judge's conviction in deciding the case.

\section{d. Circumstantial evidence in evidence instruments}

The guidance in Article 188 of the Criminal Procedure is defined as an act, event, or circumstance due to its correspondence, either between the other and the offense itself, indicating that there has been a crime and who the perpetrator is. In contrast to other evidences, evidence evidence obtained from testimony of witnesses, letters, and the statement of the defendant. Understanding "obtained" means evidence evidence is not direct evidence (Alfitra, 2012: 103). The word "signifies" in Article 188 paragraph 1 of the Criminal Procedure Code means that from the evidence evidence there is no absolute certainty. The word suitability in the same article is the main force of the guidance as evidence because of the suitability between one another in the case of deeds, events, or circumstances, then the judge becomes convinced of the deed done by the defendant. The task of the judge is more difficult in using evidence evidence because having to search for a relationship between an action, event, or circumstance mustÿthen draw conclusions and combine the consequences to a decision about whether or not something has been prosecuted.

This case entirely uses indirect evidence because there is no evidence to prove directly that the defendant committed a crime of premeditated murder. On the basis of such circumstances, the judge considers indirect evidence or circumstantial evidence in deciding cases. As long as the judge's correspondence is obtained from the testimony of the witness, the 
defendant's statement, and the letter, the evidence evidence may be acknowledged as a valid evidence by the KUHAP in the proving of a criminal case as long as it meets the requirements set forth therein. The requirements for a hint are as follows: (Syaiful Bakhri, 2015: 131-132)

1) The existence of the corresponding acts, events and circumstances, acts, events and circumstances are facts indicating the existence of a criminal offense, indicating the defendant committed, and indicating the defendant is guilty of committing the offense.

2) There are two conformities, namely between each occurrence and the circumstances of each other, or in accordance with the deeds, events, or circumstances with the indicted crime.

3) Such a conformity indicates or indicates the existence of two things, which indicates that the true crime has occurred and indicates who the perpetrator is. This element is the conclusion of the workings of the process of forming evidence evidence.

4) Can only be established, through three evidences, namely witness statements, letters, and statements of defendants, in accordance with a minimum of valid evidence.

e. Circumstantial evidence in the statement of the defendant

The defendant's description in the context of the law of evidence in general can be equated with the proof of recognition so that if there is no other corroborating evidence then a defendant's accusation or information is of no value (Richard A.Leo, 2008: 195). In terms of terminology, between recognition and description there are differences in meaning but in essence the two words are not contradictory. In the term "description of the accused" at the same time encompassing "confessions" and "denials", the "confession of the accused" is limited to the statement of recognition itself. The definition of the defendant's description is broader than the acknowledgment. Therefore, using the description of the defendant can be said to be more advanced than the defendant's accusation (Alfitra, 2012: 110-111).

The defendant's statements contained in Article 189 paragraph (3) of the Criminal Procedure Code that the defendant's statements can only be used against himself, so in the following paragraph it is clear that the defendant's statements alone are not sufficient to prove that he is guilty of committing the deed charged to him but must be accompanied by evidence another. According to this principle, 
what one declares in his position as defendant, only if in a case the defendant is made up of several persons, each of the statements of each defendant is merely a binding means of evidence to himself. A defendant's description can not be used against defendant B, nor vice versa (Yahya Harahap, 2010: 321).

The defendant's statement is about his own actions, or known and experienced by the defendant himself (Syaiful Bakhri, 2015: 79). As described in the preceding sub-chapter on the circumstantial evidence, it can be concluded that the theory views on whether or not the evidence can directly indicate the offense committed by the defendant or not. So that the defendant's statement can also be a direct evidence when the defendant himself acknowledges the crime he has committed. However, it should be recalled in Article 189 paragraph (4) of the Criminal Procedure Code that the statement of defendant is not sufficient to prove that he is guilty of committing the deed charged to him, but must be accompanied by other evidence. So that the direct evidence given by the defendant about his admission directly does not automatically judge the guilty verdict but needs to consider the evidence other than the defendant's description.

There is also a statement of the defendant in the form of circumstantial evidence in which the statement is not in the form of recognition but other statements that are related to other evidence or the crime itself. It is certainly juridical can be used as legal evidence. Besides the defendant has a right of disgrace, not necessarily a defendant was found guilty of committing a criminal act that was charged.

\subsubsection{Circumstantial evidence outside the Criminal Procedure Code}

The use of circumstantial evidence theory is not entirely recognized by law, especially the Criminal Procedure Code, because the Criminal Procedure Code has regulated in such a way as to legal evidence and explanatory rules concerning it. After knowing which circumstantial evidence is recognized by the Criminal Procedure Code, we also need to review the juridical matters concerning the outside evidences described above. However, the Criminal Procedure Code has regulated the valid evidence in Article 184 so that evidences with evidence other than the types of evidence mentioned in Article 184 paragraph (1) of the Criminal Procedure Code have no binding evidentiary power. Thus, both the Panel of Judges presiding over the case, the Public Prosecutor and the Defendant or the Legal Counsel in providing a description of limited and limited juridical analysis using valid legal evidence as intended by the Criminal Procedure Code. 
So that we can draw the conclusion that the tool prove that the basis for the judge in deciding whether the defendant is guilty or not (O.C.Kaligis, 2011: 4). This is due to the Indonesian proof system using Negatief Wettelijke bewijstheorie.

The judge's conviction must be based on at least two evidences so that it must be ensured that the evidence is a legal proof of the jurisdiction. Based on the author's analysis, in addition to the use of juridical acknowledgment, there are also circumstantial evidence not recognized by the Criminal Procedure Code used in Decision Case No 777 / Pid.B / 2016 / PN Jakarta Pusat,

\section{E. CLOSING}

\section{Conclusion}

Juridical Approach on the use of circumstantial evidence in the proving of a criminal case, especially in Decision Number 777 / Pid.B / 2016 / PN Jakarta Pusat, is divided into two that are recognized by KUHAP and which are not recognized. Circumstantial evidence acknowledged by the Criminal Procedure Code is the circumstantial evidence used in the testimony of witnesses, expert statements, letters, directives, and statements of defendants which can not directly indicate a perpetrator commits a crime but the evidence refers to a fact and by such fact can refer to the actual event. Not only that, its use is also limited by the descriptions contained in the articles of the Criminal Procedure Code. The use of circumstantial evidence that is not recognized by the Criminal Procedure Code is of course a use which is not in accordance with the provisions set forth in Article 183-189 Criminal Procedure Code or other laws regulating other special evidences. For example, observations of judges, testimony of witnesses only substantiated by evidence, evidence of evidence obtained other than the testimony of witnesses, statements of the accused, and the letter.

\section{Suggestion}

It is hoped that the theory of circumstantial evidence can be used in the proofing process in Indonesia considering the development of crime that has been such and sometimes difficult in terms of proof. In the proof of crime with minimal evidences, it is hoped that this theory can be used to establish an evidence that works indirectly which is expected to be applied to all valid evidence according to the Criminal Procedure Code, subject to the minimum provision of evidence in accordance with Article 184 KUHAP. 


\section{BIBLIOGRAPHY}

Books:

Adami Chazawi, Adami, 2008, Hukum Pembuktian Tindak Pidana Korupsi (The Law of Evidence of Corruption), Alumni: Bandung

Alfitra, 2012, Hukum Pembuktian dalam Beracara Pidana, Perdata, dan Korupsi di Indonesia (The Law of Evidence in The Criminal Procedur, Privat, Corruption Law in Indonesia), Raih Asa Sukses: Jakarta.

Arief, Barda Nawawi, 2009, Hukum Pidana I (Criminal Law I), Semarang : Yayasan Soedarto d/a Fakultas Hukum Undip.

Basrowi dan Suwandi, 2008, Memahami Penelitian Kualitatif (Understanding Qualitative Research), Rinneka Cipta: Jakarta.

Colin Evans, Colin, 2010, Criminal Justice Evidence, Chelsea House Publisher: New York

Hamzah, Andi, 2004, Hukum Acara Pidana (Criminal Procedur Law), Sinar Grafika: Jakarta.

Harahap, M Yahya, 2000, Pembahasan Permasalahan dan Penerapan KUHAP (Discussion of The Problem and Implementation of KUHAP), Sinar Grafika: Jakarta.

, 2010, Pembahasan Permasalahan dan Penerapan KUHAP (Pemeriksaan Sidang Pengadilan, Banding, Kasasi, dan Peninjauan Kembali), Sinar Grafika: Jakarta..

Hiarej, Eddy O.S, 2012, Teori dan Hukum Pembuktian (Theory and Law of Evidence), Erlangga: Jakarta.

Jalaluddin Rakhmad, Jalaluddin, 1995, Kamus Filsafat (Philosophic Dictionary), Rosda Karya: Jakarta.

Kaligis, O.C., 2011, Pendapat Ahli dalam Perkara Pidana (Doctrine on the Criminal Matters), Alumni: Bandung.

Leo, Richard A, 2008, Police Interrogation and American Justice, Harvard University Press: England.

Marpaung, Leden, 2010, Proses Penanganan Perkara Pidana di Kejaksaan dan Pengadilan Negeri (Upaya Hukum dan Eksekusi (Criminal Case Handling Process in The Attorney and District Court), Sinar Grafika: Jakarta.

Masyhar, Ali, 2016, Quo Vadis Pendidikan Hukum Kita. Prosiding Vol VIII. Universitas Negeri Jakarta. : Konvensi Nasional Pendidikan Indonesia, 1216 Oktober 2016 
Max M Houck, Max M, 2009, Essentials of Forensik Science : Trace Evidence, Infobase Publishing: New York.

Muladi dan Barda Nawawi Arief, 1984, Teori-teori Kebijakan Pidana (Theories on Criminal Policy), Alumni: Bandung.

Ranuhandoko. 1996, Terminologi Hukum (Legal Terminology), Sinar Grafika: Jakarta.

Scharffs, Brett G, 2004, The Character of Legal Reasoning" Whasington and Lee Law Review. Ed 6.

Sidabutar, Mangasa, 2001, Hak Terdakwa, Terpidana, dan Penuntut Umum Menempuh Upaya Hukum (Rights on Defendant, Convicted, and General Attorney to Take Legal Action), RajaGrafindo Persada: Jakarta:.

Syaiful Bakhri, Syaiful, 2009, Hukum Pembuktian dalam Praktik Peradilan Pidana (Law of Evidence in The Criminal Court Practice), Total Media: Yogyakarta.

, 2012, Beban Pembuktian dalam Beberapa Praktik Peradilan (Burden of Proof in The Judicial Practices), Gramata Publishing: Bekasi.

, 2015, Sistem Peradilan Pidana Indonesia: dalam Perspektif Pembaruan, Teori, dan Praktik Peradilan (Indonesia Criminal Justice System), Pustaka Pelajar:Yogyakarta.

\section{Journals:}

Kasworo, Yerrico. 2016. "Pembunuhan dengan Rencana dan Pasal 340 KUHP". Jurnal Rechts Vinding : Media Pembinaan Hukum Nasional.

Ritonga, Rena Zefania dan Vicariya Retnowati Boong . 2016. "Keabsahan Alat Bukti Elektronik dalam Hukum Acara Pidana di Indonesia" Jurnal Dspace UPH Surabaya.

Wijayanti, Alcadini, dkk. 2012. "Perkembangan Alat Bukti Dalam Pembuktian Tindak Pidana Berdasarkan Undang Undang Khusus Dan Implikasi Yuridis Terhadap KUHAP". Diponegoro Law Review, Volume 1 Nomor 4. 